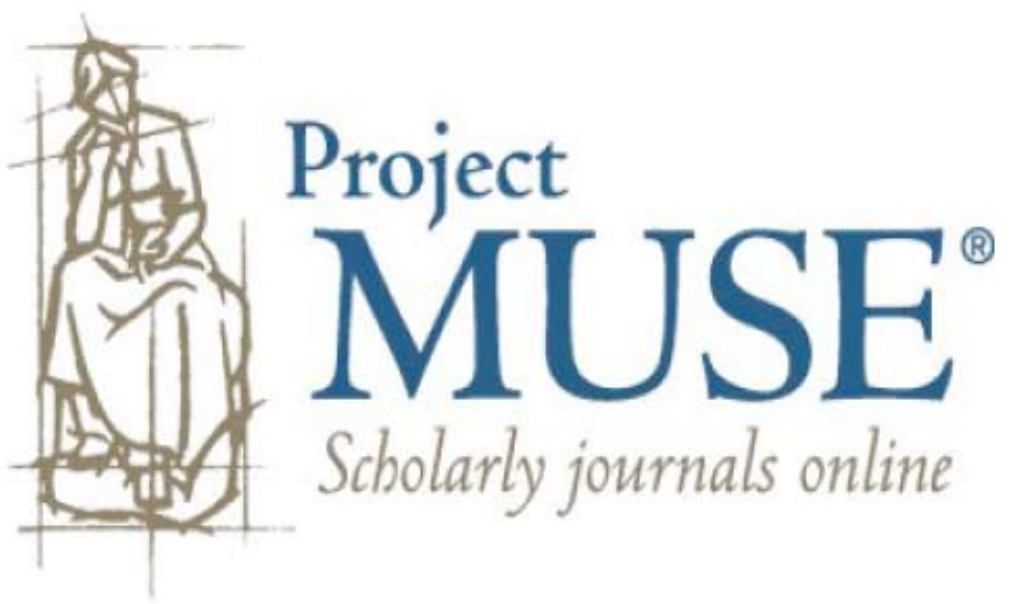




\title{
Powerlessness ANd Social Interpretation
}

\begin{abstract}
Our understanding of social experiences is central to our social understanding more generally. But this sphere of epistemic practice can be structurally prejudiced by unequal relations of power, so that some groups suffer a distinctive kind of epistemic injustice-hermeneutical injustice. I aim to achieve a clear conception of this epistemicethical phenomenon, so that we have a workable definition and a proper understanding of the wrong that it inflicts.
\end{abstract}

I want to explore the idea that social understanding-in particular our understanding of our own social experiences-is a sphere of epistemic activity in which relations of identity and power can create a particular kind of epistemic injustice, with the upshot that some social groups are unable to dissent from distorted understandings of their social experiences. To see better what the contours of such an injustice might be, let us begin with a historical example drawn from Susan Brownmiller's memoir of the U.S. Women's Liberation Movement, which concerns the experience of what we are these days in a position to name sexual harassment:

Carmita Wood, age forty-four, born and raised in the apple orchard region of Lake Cayuga, and the sole support of two of her children, had worked for eight years in Cornell's department of nuclear physics, advancing from lab assistant to a desk job handling administrative chores. Wood did not know why she had been singled out, or indeed if she had been singled out, but a distinguished professor seemed unable to keep his hands off her.

As Wood told the story, the eminent man would jiggle his crotch when he stood near her desk and looked at his mail, or he'd deliberately brush against her breasts while reaching for some papers. One night as the lab workers were leaving their annual Christmas party, he cornered her in the elevator and planted some unwanted kisses on her mouth. After the Christmas party incident, Carmita Wood went out of her way to use the stairs in the lab building in order to avoid a repeat encounter, but the stress of the furtive molestations and her efforts to keep the scientist at a distance while maintaining cordial relations with his wife, whom she liked, brought on a host of physical symptoms. Wood developed chronic back and neck pains. Her right thumb tingled and grew numb. She requested a transfer to another department, and when it didn't come through, she quit. She walked out the door and went to Florida for some rest and recuperation. Upon her return she applied for unemployment insurance. When the claims investigator asked why she had left her job after eight years, Wood was at a loss to describe the hateful episodes. She was ashamed and embarrassed. Under prodding-the blank on the form needed to be filled in-she answered that her reasons had been personal. Her claim for unemployment benefits was denied. 
'Lin's students had been talking in her seminar about the unwanted sexual advances they'd encountered on their summer jobs', Sauvigne relates. 'And then Carmita Wood comes in and tells Lin her story. We realized that to a person, every one of us - the women on staff, Carmita, the students- had had an experience like this at some point, you know? And none of us had ever told anyone before. It was one of those click, aha! moments, a profound revelation.'

... Meyer located two feminist lawyers in Syracuse, Susan Horn and Maurie Heins, to take on Carmita Wood's unemployment insurance appeal. 'And then ...' Sauvigne reports 'we decided that we also had to hold a speak-out in order to break the silence about this.'

The 'this' they were going to break the silence about had no name. 'Eight of us were sitting in an office of Human Affairs,' Sauvigne remembers, 'brainstorming about what we were going to write on the posters for our speak-out. We were referring to it as 'sexual intimidation,' 'sexual coercion,' 'sexual exploitation on the job.' None of those names seemed quite right. We wanted something that embraced a whole range of subtle and unsubtle persistent behaviors. Somebody came up with 'harassment.' Sexual harassment! Instantly we agreed. That's what it was' (Brownmiller 1990, 280-I).

Here is a story about how extant collective hermeneutical resources can have a lacuna where the name of a distinctive social experience should be. So described, we can see that women such as Carmita Wood suffered (among other things) an acute cognitive disadvantage from a gap in the collective hermeneutical resource. But this description does not quite capture it, for if the epistemic wrong done to Carmita Wood were construed simply as a matter of plain cognitive disadvantage, then it is unclear why the epistemic wrong is suffered only by her and not also by her harasser. For the lack of proper understanding of women's experience of sexual harassment was a collective disadvantage more or less shared by all. Prior to the collective appreciation of sexual harassment as such, the absence of a proper understanding of what men were doing to women when they treated them like that was ex bypothesi quite general. Different groups can be hermeneutically disadvantaged for all sorts of reasons, as the changing social world frequently generates new sorts of experience of which our understanding may dawn only gradually, but only some of these cognitive disadvantages will strike one as unjust. For something to be an injustice it must be harmful but also wrongful, whether because discriminatory or otherwise unfair. In the present example, harasser and harassee alike are cognitively handicapped by the hermeneutical lacuna-neither has a proper understanding of how he is treating her-but the harasser's cognitive disablement is not a significant disadvantage to him. Indeed there is an obvious sense in which it suits his purpose. (Or at least it suits his immediate purpose in that it leaves his conduct unchallenged. This is not to deny that if he is a decent person underneath, so that a better understanding of the seriousness of his bad behaviour would have led him to refrain, then the hermeneutical lacuna is for him a source of epistemic and moral bad luck.) By contrast, the harassee's cognitive disablement is seriously disadvantageous to her. The cognitive disablement prevents her from understanding an important patch of her own experience; that is, a patch of experience which it is strongly in her interests to understand, for without that understanding she is left deeply troubled, confused, and isolated, not to mention vulnerable to continued harassment. Her hermeneutical disadvantage renders her unable to make sense of her ongoing mistreatment, and this in turn prevents her from protesting it, let alone securing effective measures to stop it. 
The fact that the hermeneutical lacuna creates such an asymmetrical disadvantage for the harassee already fuels the idea that there is something wrongful about her cognitive disadvantage in particular. We would not describe her as suffering an injustice if it were not significantly disadvantageous for her in particular. But there is more than this to be said about the wrong that she sustains. We need to find the deeper source of the intuition that she incurs an injustice. We can easily imagine, after all, similarly serious hermeneutical disadvantages that do not inflict any epistemic injustice. If, for instance, someone has a certain medical condition affecting their behaviour at a historical moment at which that condition is still misunderstood and largely undiagnosed, then they may suffer a hermeneutical disadvantage that is, while collective, especially damaging to them in particular. They are unable to render their experiences intelligible by reference to the idea that they have a disorder, and so they are personally in the dark, and may also suffer seriously negative consequences from others' non-comprehension of their condition. But they are not subject to hermeneutical injustice; rather, theirs is a poignant case of circumstantial epistemic bad luck. In order to find the deeper source of the intuition that there is an epistemic injustice at stake in our example from Brownmiller we should focus on the background social conditions that were conducive to the relevant hermeneutical lacuna. Women's position at the time of second wave feminism was still one of marked social powerlessness in relation to men; and, specifically, the unequal relations of power prevented women from participating on equal terms with men in those practices by which collective social meanings are generated. Most obvious among such practices are those sustained by professions such as journalism, politics, academia, and law-it is no accident that Brownmiller's memoir recounts so much pioneering feminist activity in and around these professional spheres and their institutions. Women's powerlessness meant that their social position was one of unequal hermeneutical participation, and something like this sort of inequality provides the crucial background condition for the epistemic injustice affecting Carmita Wood.

\section{HERMENEUTICAL MARGINALIZATION AND HERMENEUTICAL INJUSTICE}

Hermeneutical inequality is an epistemic inequality that arises from social inequality, and it is inevitably hard to detect. Our interpretive efforts are naturally geared to interests, as we try hardest to understand those things it serves us to understand. Consequently, a group's unequal hermeneutical participation will tend to show up in a localised manner in hermeneutical hotspots-locations in social life where the powerful have no interest in achieving a proper interpretation, perhaps indeed where they have a positive interest in sustaining the extant misinterpretation (such as that repeated sexual propositions in the workplace are necessarily just a way of 'flirting', and their uneasy rejection by the recipient a matter of her 'lacking a sense of humour'). But then in such a hotspot as this, the unequal hermeneutical participation remains positively disguised by the existing meaning attributed to the behaviour ('flirting'...), and so it is all the more difficult to detect. No wonder that moments of its revelation can come as a life-changing flash of enlightenment. Unlike our example of a person with a condition for which medical science does not yet have the proper diagnosis, what women like Carmita Wood had to 
contend with at work was no plain epistemic bad luck, for it was no accident that their experience had been falling down the hermeneutical cracks. As they struggled in isolation to make proper sense of their various experiences of harassment, the whole engine of collective social meaning was effectively geared to keeping these obscured experiences out of sight. Her unequal hermeneutical participation is the deeper reason why Carmita Wood's cognitive disablement constitutes an injustice.

Let us say that when there is unequal hermeneutical participation with respect to some significant area $(\mathrm{s})$ of social experience, members of the disadvantaged group are hermeneutically marginalized. The notion of marginalization is a moral-political one indicating subordination and exclusion from some practice that would have value for the participant. Obviously there can be more and less persistent and/or wide-ranging cases of hermeneutical marginalization. Although the term will be most at home in cases where the subject is persistently denied full hermeneutical participation in respect of a wide range of social experiences, nonetheless we can apply the term in slighter cases. Thus someone might be hermeneutically marginalized only fleetingly, and/or only in respect of a highly localized patch of their social experience. But hermeneutical marginalization is always socially coerced. If you simply opt out of full participation in hermeneutical practices as a matter of choice (perhaps, fed up with it all, you become a modern hermit) then you do not count as hermeneutically marginalized-you've opted out but you could have opted in. Hermeneutical marginalization is always a form of powerlessness, whether structural or one-off.

Social subjects of course have more or less complex social identities, and so one might be marginalized in a context where one aspect of one's identity is to the fore ('woman') but not in other contexts where other aspects of one's identity are determining one's level of participation ('middle-class'). The net result is that while a hermeneutically marginalized subject is prevented from generating meanings pertaining to some areas of the social world, she might well maintain a fuller participation as regards others. If she has a well-paid job in a large corporation with a macho work ethic she may be entirely unable to frame meanings, even to herself, relating to the need for family-friendly working conditions (such sentiments can only signal a lack of professionalism, a failure of ambition, a half-hearted commitment to the job), and yet she may be in a hermeneutically luxurious position as regards her ability to make sense of other, less gendered, areas of her work experience. Thus the complexity of social identity means that hermeneutical marginalization afflicts individuals in a differentiated manner; that is, it may afflict them qua one social type, but not another.

We can now define hermeneutical injustice of the sort suffered by women like Carmita Wood. It is: the injustice of having some significant area of one's social experience obscured from collective understanding owing to persistent and wide-ranging hermeneutical marginalization. But the latter notion is cumbersome, and we would do well to make our definition slightly more explicit in terms of what is bad about hermeneutical marginalization of the persistent and wide-ranging sort. From the epistemic point of view, what is bad about this sort of hermeneutical marginalization is that it renders the collective hermeneutical resource structurally prejudiced, for it will tend to issue interpretations of that group's social experiences that are biased because insufficiently 
influenced by the subject group and therefore unduly influenced by more hermeneutically powerful groups (thus, for instance, sexual harassment as flirting, rape in marriage as non-rape, post-natal depression as hysteria, reluctance to work family-unfriendly hours as unprofessionalism, and so on). We can now colour our definition slightly differently, without altering its substance, so that it better conveys the discriminatory nature of hermeneutical injustice. Hermeneutical injustice is: the injustice of having some significant area of one's social experience obscured from collective understanding owing to a structural prejudice in the collective hermeneutical resource.

Our definition has grown out of the effort to identify the sort of hermeneutical injustice suffered by Carmita Wood, and as a result the definition is not generic. Rather it specifically captures what we might call the systematic case of hermeneutical injustice. Now what exactly does 'systematic' mean here? The thought is that some groups may suffer marginalization in respect of only one localized area of their social life, whereas others-those perhaps like Carmita Wood-are also marginalized economically, and/ or politically, educationally, professionally, and so on. (Indeed, in cases of systematic hermeneutical injustice, the hermeneutical marginalization entails marginalization of at least a socio-economic sort, since it entails non-participation in professions that make for significant hermeneutical participation such as journalism, politics, law, and so on.) Let us say, then, that if marginalization pursues the subject through a range of different dimensions of social activity besides the hermeneutical, then any hermeneutical injustices to which it gives rise are systematic. Systematic hermeneutical injustices are part of the broad pattern of a social group's general susceptibility to different sorts of injustice. We should think of systematic hermeneutical injustice as the central case-it is central from the point of view of an interest in how epistemic injustice is woven into the fabric of social injustice more generally.

By contrast, there can be cases of hermeneutical injustice that are not part of the general pattern of social power, and are more of a one-off. They are not systematic but incidental. Whereas systematic cases will tend to involve persistent and wide-ranging hermeneutical marginalization, incidental cases will tend to involve hermeneutical marginalization only fleetingly and/or in respect of a highly localized patch of the subject's experience. Incidental hermeneutical injustices, then, stem not from any structural inequality of power but rather from a more one-off moment of powerlessness. What might an incidental case of hermeneutical injustice look like? In Ian McEwan's novel Enduring Love the main protagonist, Joe, is stalked by a young man called Jed Parry, a religious fanatic with delusions of love between him and Joe. When Joe tells his partner, Clarissa, about it he meets first affectionate derision and then, later-although she accepts the basics of what he is telling her-her reaction is more one of concerned reserve about his state of mind. When, subsequently, he calls the police, Joe finds that the form of stalking he is enduring does not make the legal grade and is represented as trivial:

\footnotetext{
'Are you the person being harassed?'

'Yes. I've been...'

And is the person causing the nuisance with you now?'

'He's standing outside my place this very minute.'

'Has he inflicted any physical harm on you?'
} 
'No, but he...'

'Has he threatened you with harm?'

'No.' I understood that my grievance would have to be poured into the available bureaucratic mould. There was no facility refined enough to process every private narrative. Denied the release of complaint, I tried to take comfort in having my story assimilated into a recognisable public form. Parry's behaviour had to be generalised into a crime.

'Has he made threats against your property?'

'No.'

'Or against third parties?'

'No.'

'Is he trying to blackmail you?'

'No.'

'Do you think you could prove that he intends to cause you distress?'

'Er, no.'

... 'Can you tell me what he's doing then?'

'He phones me at all hours. He talks to me in the ...'

The voice was quick to move back to his default position, the interrogative flow chart. 'Is he using obscene or insulting behaviour?'

'No. Look, officer. Why don't you let me explain. He's a crank. He won't let me alone.'

'Are you aware of what he actually wants?' ...

'He wants to save me.'

'Save you?'

'You know, convert me. He's obsessed. He simply won't leave me alone.'

The voice cut in, impatience taking hold at last. 'I'm sorry caller. This is not a police matter. Unless he harms you, or your property, or threatens the same he's committing no offence. Trying to convert you is not against the law.' Then he terminated our emergency conversation with his own little stricture. 'We do have religious freedom in this country.' (McEwan I998, 73-74)

Joe's own understanding of his experience of being stalked is only slightly hindered by the lack of hermeneutical reciprocation by partner and police, but still a collective hermeneutical lacuna is preventing him from rendering his experience communicatively intelligible. It is very much in his interests to share his experience with certain others from the off; but he cannot, for the true nature of his experience of being stalked by Jed Parry is obscured by two misfit interpretations that trivialize it in different ways. According to one he seems to be failing to see the funny side and becoming worryingly obsessed; according to another he is exaggerating the level of threat and even cramping someone else's religious freedom into the bargain. But if the obscurity of Joe's experience constitutes a kind of hermeneutical injustice, this has nothing to do with any general social powerlessness or any general subordination as a generator of social meaning, for his social identity is that of the proverbial white, educated, straight man. Still he is none the less up against a one-off moment of hermeneutical marginalization. The competing and trivializing interpretations coming from Clarissa and the police respectively mean that Joe's hermeneutical participation is hindered in respect of a significant, if highly localized, patch of his social experience, and for this reason his case qualifies as a hermeneutical injustice. The injustice does not stem from any structural prejudice in hermeneutical resources-on the contrary, he suffers the injustice not because of but 
rather in spite of the hermeneutical ease he normally enjoys, indeed in spite of his general position of social power. Clearly Joe's hermeneutical injustice is not a systematic case; it is incidental.

Awareness of such cases motivates a more generic definition of hermeneutical injustice than those so far given, which were designed to capture what we can now more clearly see to be the distinctively systematic case. The generic definition now called for captures hermeneutical injustice per se as: the injustice of having some significant area of one's social experience obscured from collective understanding owing to hermeneutical marginalization. This definition simply omits what is special to the systematic case, namely that the hermeneutical marginalization is 'persistent and wide-ranging', or, equivalently, that there is a 'structural prejudice in the collective hermeneutical resource'. This generic definition, then, covers both the systematic case and the incidental case. As ever, the systematic case is central from our point of view. The non-centrality of incidental cases does not entail ethical triviality. Indeed it is life-shattering for Joe that his experience is not better understood from the start, since this allows Jed Parry's stalking to escalate to ultimately mortally threatening levels, and it contributes too to the eventual collapse of his long relationship with Clarissa. Incidental hermeneutical injustices can be every bit as harmful as systematic ones.

We have encountered, then, two sorts of hermeneutical injustice: systematic and incidental. If someone is disadvantaged, as for instance Joe is, from having their experience left obscure owing to a lacuna in the collective hermeneutical resource, then that is broadly sufficient for a claim of incidental hermeneutical injustice, even though the hermeneutical marginalization is localized and one-off. By contrast, if someone is disadvantaged, as for instance Carmita Wood is, by having their experience left obscure owing to a lacuna in the collective hermeneutical resource, where the lacuna is caused and maintained by a wide-ranging and persistent hermeneutical marginalization, then the hermeneutical injustice is systematic. For in such cases the hermeneutical marginalization is part of a more general susceptibility to different forms of social marginalization, so that any given hermeneutical injustice incurred is likewise part of a more general susceptibility to different kinds of injustice. Whether the injustice is of the systematic or the incidental kind, it involves no perpetrator, no culprit. Hermeneutical injustice is a structural notion, for it is a form of inequality-it is an epistemic inequality. The background condition for hermeneutical injustice is the subject's hermeneutical marginalization. And the actual moment of hermeneutical injustice comes when the background condition expresses itself in a more or less doomed attempt on the part of the subject to render an experience intelligible, either to herself or to an interlocutor. The hermeneutical inequality that exists, dormant, in a situation of hermeneutical marginalization erupts in injustice only when some actual attempt at intelligibility is handicapped by it.

Now that we have a clear idea of what defines hermeneutical injustice, in its systematic and incidental forms, let us try to probe the nature of the wrong it does to the subject whose interpretive efforts at social understanding are hampered by it. 


\section{THE WRONG OF HERMENEUTICAL INJUSTICE}

I have talked in terms of hermeneutical injustice involving an asymmetrical cognitive disadvantage. The general point here is that collective hermeneutical impoverishment impacts on members of different groups in different ways. It did not harm the interests of Carmita Wood's harasser that he (as the example goes) did not have a proper grasp of the nature of his treatment of her; but it harmed Carmita Wood a great deal that she could not make adequate sense of it to herself, let alone to others. The asymmetry arises from the concrete social and practical context in which the collective hermeneutical impoverishment impinges. It is only when the collective impoverishment is concretely situated in specific social situations that it comes to be especially and unjustly disadvantageous to some groups and not others. Hermeneutical lacunas are like holes in the ozone-it's the people who live under them that get burned. Fundamentally, then, hermeneutical injustice is a kind of structural discrimination. Compare a society that has a welfare state providing free healthcare at the point of delivery, but where there is a gap in state provision: no free dental care. Formally speaking, there is nothing intrinsically unjust about there being a general lack of free dental care, for it is the same for everyonethere is, so to speak, a collective lacuna in the welfare system. There is a formal equality, then; but as soon as one looks to how this formal equality plays out in practice in the lived social world, a situated inequality quickly reveals itself: people who cannot afford private dental care suffer from the lack of general provision, and people who can do not. In such cases of formal equality but lived inequality, the injustice is a matter of some group(s) being asymmetrically disadvantaged by a blanket collective lack, and so it is, I suggest, in the case of hermeneutical injustice. A hermeneutical injustice is done when a collective hermeneutical gap impinges so as to significantly disadvantage some group(s) and not others, so that the way the collective impoverishment plays out in practice is effectively discriminatory. Let us say, then, that the primary harm of hermeneutical injustice consists in a situated hermeneutical inequality: the concrete situation is such that the subject is rendered unable to make communicatively intelligible something which it is particularly in his or her interests to be able to render intelligible.

Such is the primary harm. But there are also secondary harms, caused by the primary one, that may be usefully distinguished. The primary harm of situated hermeneutical inequality must, by definition, issue in further practical harms-those harms which render the collective hermeneutical impoverishment asymmetrically disadvantageous to the wronged party. To illustrate, let us simply remind ourselves of Carmita Wood's story. The primary epistemic harm done to her was that a patch of her social experience which it was very much in her interests to understand was not collectively understood and so remained barely intelligible even to her. From the story we can see that among the secondary harms caused by this were that she developed physical symptoms of stress, could not apply successfully for a transfer owing to the fact that she had no nameable reason to cite, and eventually simply had to quit her job. Further, when she came to apply for unemployment benefits, the lack of a name for the cause of all this again guaranteed that she lost out-she was refused the benefits. A little imagination allows one to see how far-reaching the ramifications of such a case of hermeneutical injustice could be. 
If Carmita Wood, and other women like her, had never gone to consciousness-raising, the experience of sexual harassment would have remained under wraps for much longer and would have done more to ruin the professional advancement, the personal selfconfidence and, most relevantly here, the general epistemic confidence of women than it was in fact allowed to do, thanks to second wave feminism. When you find yourself in a situation where you seem to be the only one to feel the dissonance between received understanding and your own intimated sense of a given experience it tends to knock your faith in your own ability to make sense of the world, or at least the relevant region of the world. We can see, then, that not only does hermeneutical injustice have knockon practical disadvantages for the subject, it also has epistemic disadvantages associated with it.

The sorts of epistemic disadvantages at stake stem most basically from the subject's loss of epistemic confidence. Many conceptions of knowledge implicitly or explicitly cast some sort of epistemic confidence as a condition of knowledge, whether it comes in as part of the belief condition, or as part of a justification condition. If we are to name one seminal epistemological view in this connection, then it must surely be Descartes's idea that a state of absolute confidence in one's belief - a state of certainty-is requisite for knowledge, for the some such internalist assumption has made itself felt in so many conceptions of knowledge subsequently. The significance for the present discussion is that, on any confidence-including conception of knowledge, the implications for someone whose epistemic performance is affected by hermeneutical injustice are grim: not only is he repeatedly subject to the primary harm, but where this causes him to lose confidence in his beliefs and/or his justification for them, he literally loses knowledge. Perhaps some piece of knowledge he possesses is washed away in a one-off wave of underconfidence. Or perhaps he suffers a prolonged erosion of epistemic confidence so that he is ongoingly disadvantaged, repeatedly failing to gain items of knowledge he would otherwise have been able to gain.

A less direct way in which someone's general loss of epistemic confidence might result in an ongoing failure to gain knowledge is by preventing him from developing certain intellectual virtues. Most notably, for instance, loss of epistemic confidence is likely to inhibit the development of intellectual courage, the virtue of not backing down in one's convictions too quickly in response to challenge. This is an important feature of epistemic function. James Montmarquet categorizes the epistemic virtues into those of 'impartiality', 'intellectual sobriety', and 'intellectual courage', where this last category includes 'most prominently the willingness to conceive and examine alternatives to popularly held beliefs, perseverance in the face of opposition from others (until one is convinced one is mistaken), and the determination required to see such a project through to completion' (Montmarquet 1993, 23). These different virtues relating to intellectual courage require epistemic confidence and are obviously susceptible to erosion by hermeneutical injustice. So if a history of such injustices gnaws away at a person's intellectual confidence, or never lets it develop in the first place, this damages his epistemic function quite generally. The under-confident subject will tend to back down too soon in the face of challenge, or even at the very prospect of it, and this tendency may well deprive him of knowledge he would otherwise have gained. In such a case there will be a series of specific deprivations 
of knowledge-beliefs or hypotheses that are given up too quickly-where some of these epistemic deprivations may constitute significant losses. More generally, and quite apart from the obvious fact that feelings of under-confidence are generally unpleasant in themselves, there is also an epistemic loss to the subject in terms of his intellectual character. The value of an intellectual virtue is not reducible to the value of those particular items of knowledge it might bring, but derives also from its place in the harmony of a person's intellectual character taken as a whole. Whatever the consequences may or may not be for the subject in terms of knowledge loss, an enduring loss of intellectual confidence entails a certain regrettable malformation of epistemic character.

\section{UNJUST SOCIAL CONSTRUCTIONS}

With the primary and secondary aspects of the wrong of hermeneutical injustice set out, perhaps we can now dig a little deeper into the nature of the primary aspect-the situated hermeneutical inequality - to see whether it might sometimes affect not only one's understanding of one's experiences but one's very social identity. Can hermeneutical injustice impact on the very development of self? Consider a new example. In Edmund White's autobiographical novel, A Boy's Own Story, which tells the story of his growing up in nineteen-fifties America, we are presented with many different ways in which the hermeneutical resources of the day burden his sexual experience with layers of falsifying meaning. As he grows up he has to contend with various powerful bogeymen constructions of what it is to be a Homosexual. None of them fits, but these collective understandings are so powerful, and the personal experiential promise of an alternative understanding so lonely and inarticulate, that they have some significant power to construct not only the subject's experience (his desire becomes shameful and so on) but also his very social being. Not without a fight, for sure, and this autobiographical story presents us above all with a young person who wrestles these bullying would-be selves with courage and wit, now giving in to their bid to claim his identity, now resisting. This is explicit in a passage that recounts a visit to a psychoanalyst, Dr O'Reilly. Here we see how one version of the unnatural homosexual-as a vampire-like version of a man-leads our adolescent subject to fear the name, and to experience his own nascent identity as a homosexual as a terrifying prospect, something to be pre-empted at all costs and, in so far as it already exists, disguised:

Just as years before, when I was seven, I had presented myself to a minister and had sought for his understanding, in the same way now I was turning to a psychoanalyst for help. I wanted to overcome this thing I was becoming and was in danger soon of being, the homosexual, as though that designation were the mold in which the water was freezing, the first crystals already forming a fragile membrane. The confusion and fear and pain that beset me ... had translated me into a code no one could read, I least of all, a code perhaps designed to defeat even the best cryptographer....

I see now that what I wanted was to be loved by men and to love them back but not to be a homosexual. For I was possessed with a yearning for the company of men, for their look, touch and smell, and nothing transfixed me more than the sight of a man shaving and dressing, sumptuous rites. It was men, not women, who struck me as foreign and desirable and I disguised myself as a child or a man or whatever was necessary in order to enter their hushed, 
hieratic company, my disguise so perfect I never stopped to question my identity. Nor did I want to study the face beneath my mask, lest it turn out to have the pursed lips, dead pallor and shaped eyebrows by which one can always recognize the Homosexual. What I required was a sleight of hand, an alibi or a convincing act of bad faith to persuade myself I was not that vampire (White 1983, 169-70).

At some level his personal sexual experience was of a simple love of men, and yet this aspect of his experience being inarticulable, the only psychological rebellion he could hope to pull off against what this meant about his identity was denial. Denial is the first stage of the double-think (the sleight of hand, the act of bad faith) that is required in order to rebel against internalized yet falsifying hermeneutical constructions of one's social identity. For authoritative social constructions can effect a constitutive construction of one's identity, so that one comes to count socially as a vampire-like creature, even while it remains the case that one is not. Constitutive construction falls short of causal construction, for while the former is a matter of what one counts as socially, the latter is a matter of actually coming to be what one is constructed as being. White's autobiographical story gives us no particular evidence to think of him as subject to causal construction, though it is entirely plausible that being constitutively constructed as an unnatural vampire-like creature with shameful desires might encourage one to live out a familiar motif of inverted rebellion by behaving more and more like such a creature in defiant embrace of one's sins. One may be able to pull this off ironically, but then again one may not. In any case, it is enough to notice that so much of what the younger narrator is grappling with as he grows up and his social identity congeals around him can be thought of as authoritative-collectively endorsed meanings attaching to homosexuality that have the power not just to haunt him with bogeyman would-be selves but actually to constitute his social being. His sometimes playful resistance to these constructions of his identity is, as regards his social being, a matter of life and death.

To the extent that resistance is possible, part of what makes it possible is historical contingency. Our narrator had history on his side in as much as the sixties were on the horizon when all sorts of sexual liberations were to be articulated, indeed demanded. But something else that allows for resistance is that other aspects of one's identity (being educated and middle-class, perhaps) might equip one with resources for rebellion, as will certain personal characteristics (our narrator was surely fiercely intelligent, psychologically tough, and socially resourceful). Authoritative constructions in the shared hermeneutical resource, then, impinge on us collectively but not uniformly, and the non-uniformity of their hold over us can create a sense of dissonance between an experience and the various constructions that are ganging up to overpower its proper nascent meaning. As individuals, some authoritative voices have special power over us while others, for whatever reason, do not. Our narrator, for instance, is wholly untroubled by negative Christian constructions of homosexuality, for he simply does not believe in the ropes and pulleys of heaven above and eternal damnation below, and his plain anti-authoritarian impulse renders him gloriously immune to whatever remaining visceral hold religious censure might have had over him. When he spends Thanksgiving with the Scotts-the housemaster Latin teacher and his wife, both fervent Christians ambitious to convert him (and equally ambitious to seduce him, their fear of being bourgeois outstripping 
their fear of being sinners) - they introduce him to Father Burke, 'their "confessor" and spiritual guardian' (White 1983, 199):

'Well, yes', I said, 'I am seeing a psychiatrist because I have conflicts over certain homosexual tendencies I'm feeling.'

At these words Father Burke's face lurched up out of his hands. Not the nervous little confession he had expected. He recovered his poise and decided to laugh boisterously, the laugh of Catholic centuries. 'Conflicts?' he whooped, in tears of laughter by now. Then, sobering for a second, the priest added in a low, casual voice, 'But you see, my son, homosexuality isn't just a conflict that needs to be resolved' - his voice picked up these words as though they were nasty bits of refuse-'homosexuality is also a sin.'

I think he had no notion how little an effect the word $\sin$ had on me. He might just as well have said, 'Homosexuality is bad juju' (White 1983, 204).

By contrast, however, this immunity to the idea of sin is no enduring defence, for it takes almost nothing from the priest—only his identity as a priest, or perhaps simply as a straight male confessor-to conjure up a conspiracy of truly mortifying stereotypes. The passage continues:

'But I feel very drawn to other men,' I said. Although something defiant in me forced these words out, I felt myself becoming a freak the moment I spoke. My hair went bleach-blond, my wrist went limp, my rep tie became a lace jabot: I was the simpering queen at the grand piano playing concert versions of last year's pop tunes for his mother and her bridge club. There was no way to defend what I was. All I could fight for was my right to choose my exile, my destruction (204).

A person's bold sense of dissonance, then, is a fragile thing, for a construction that one is able simply to find absurd may swiftly be followed by one that holds sway over one's psyche. But at least a sense of dissonance is possible. What makes it possible is that if one finds one or more of the common constructions of one's sexuality as shameful to be manifestly false, even ridiculous, then this raises the question whether other discourses in league with it are suspect too. Finding something potentially authoritative to be absurd gives one critical courage; one hermeneutical rebellion inspires another. The sense of dissonance, then, is the starting point for both the critical thinking and the moralintellectual courage that rebellion requires. That, I take it, is part of the mechanism of consciousness raising. Put a number of people together who have felt a certain dissonance about an area of social experience, and factor in that each of them will have a different profile of immunity and susceptibility to different authoritative discourses, and it is not surprising that the sense of dissonance can find strength in numbers and become critically emboldened.

The primary harm of hermeneutical injustice, then, is to be understood not only in terms of the subject's being unfairly disadvantaged by some collective hermeneutical lacuna, but also in terms of the very construction (constitutive and/or causal) of social identity. In certain social contexts, hermeneutical injustice can mean that someone is socially constituted as, and perhaps even caused to be, something they are not, and which it is against their interests to be seen to be. Thus we can say, without essentializing, that they are prevented from becoming who they really are. Hermeneutical injustice is an 
epistemic injustice with social constructive power. It is an epistemic inequality that can bring real injury to the insult of hermeneutical marginalization. If all epistemic injustice undermines the subject specifically in his capacity as a knower, then we can identify the distinctive manner in which hermeneutical injustice does this by saying that it undermines the subject in his capacity as an interpreter of his own social experience, in his capacity, that is, for social self-knowledge.

\section{REFERENCES}

Brownmiller, S. (1990). In Our Time. Memoir of a Revolution. New York: The Dial Press. Haslanger, S. (1995). “Ontology and Social Construction," Philosophical Topics 23(2): 95-I25.

Langton, R. (1998). "Subordination, Silence, and Pornography’s Authority”. In R. Post (ed.) Censorship and Silencing: Practices of Cultural Regulation. Los Angeles: Getty Research Institute for the History of Art and the Humanities.

Lehrer, K. (1997). Self-Trust. A Study of Reason, Knowledge, and Autonomy. Oxford: Clarendon Press.

Montmarquet, J. A. (1993). Epistemic Virtue and Doxastic Responsibility. Maryland: Rowman and Littlefield.

White, E. (1983). A Boy's Own Story. London: Picador.

\section{NOTES}

I This paper is drawn from the final chapter of a forthcoming book in which I explore two distinctive kinds of epistemic injustice: testimonial injustice, in which prejudice causes a hearer to give a speaker less credibility than she otherwise would; and hermeneutical injustice - the subject of this paper. The book is forthcoming as Epistemic Injustice: Power and The Ethics of Knowing; I thank Oxford University Press for permission to publish this material here.

2 On a view such as Keith Lehrer's (1997), which accounts for knowledge in coherentist terms that make it depend upon self-trust on the part of the subject, the connection between erosion of epistemic confidence and the capacity to possess knowledge is starkly direct. (I take it that loss of epistemic confidence is equivalent to, or at least entails, loss of epistemic self-trust.)

3 For related discussions of social construction, see Rae Langton (1998); and Sally Haslanger (1995).

Miranda Fricker is Senior Lecturer in Philosophy at Birkbeck College, University of London. She has co-edited The Cambridge Companion to Feminism in Philosophy and published articles in epistemology, ethics, and feminist philosophy. Her book Epistemic Injustice: Power and the Ethics of Knowing is forthcoming with Oxford University Press. 